\title{
HAPPINESS AS A SOCIAL PHENOMENON
}

\author{
Zoriana Malynovskal, Uliana Yatsyshyn ${ }^{2}$ \\ Lviv Polytechnic National University, Lviv, Ukraine \\ ${ }^{1}$ Student of bachelor's program "Sociology", Department of Sociology and Social Work \\ ${ }^{2}$ Ph.D., Associate Professor, Department of Sociology and Social Work
}

Background: Today, the world is in a state of crisis: constant wars and conflicts have been augmented by a global pandemic that leads to social isolation, economic downturn and social uncertainty. Societies are looking for ways to preserve the quality of life that was before the pandemic, and people are trying not to lose their optimism.

Purpose: The purpose of this article is to define the concept of happiness, to specify its components and factors of formation.

Methods: Theoretical research methods were set general and specific methods and techniques of scientific knowledge are used based goal, object and subject. Analysis and synthesis methods can be used to identify and understand the concept of happiness and factors of its formation; the method of secondary data analysis was used to understand the level of happiness by the Ukrainians.

Results: The sub-active sense of happiness among Ukrainians is quite high. However, in the UNranked happiness rating, Ukraine is an outsider. The UN happiness rating is based on 6 key indicators: GDP per capita in purchasing power parity; the level of social support; healthy life expectancy; freedom to make life choices; the level of generosity; the degree of perception of corruption in the country. Sociologists also identify the following factors that affect a person's level of happiness: family, finances, work, society, friends and health.

Conclusion: The phenomenon of happiness in modern sociology has received little attention. There is no single definition of the phenomenon of happiness today. But sociologists agree that the feeling of happiness is on the one hand the individual experience of the person, and on the other - the feeling determined outside, from society (his values, well-being, level of social solidarity, etc.).

Keywords: happiness, prosperity, life satisfaction.

Феномен щастя вивчається багатьма науками, зокрема, філософією та психологією, а в контексті добробуту й задоволення життям - економікою. Соціологія не так давно вивчає це питання. Причиною тому є те, що соціологів більше цікавить те, як люди поводяться ніж те, як вони почуваються. Соціологи досліджують щастя в контексті вивчення добробуту. Класики соціології Е.Дюркгейм, О.Конт, Т.Парсонс та Г.Зіммель звернули увагу на цей феномен. Їхні думки та ідеї впливають на розвиток сучасних концепцій щастя.

Ще Платон стверджував, що коли ми будемо піклуватись про щастя інших, то самі його здобудемо. У цій думці простежується соціальний контекст, тобто наше щастя цілком залежить від людей навколо. Суспільство безпосередньо впливає на те, як ми почуваємось, знаходячись у ньому. Як наука, що вивчає різноманітні аспекти життя суспільства, соціологія досліджує соціальні фактори, які впливають на відчуття щастя i його послаблення. Соціологічні дослідження, проведені в минулому та тепер, дають змогу порівняти зміни у трактуванні щастя у різні часи, і чинники, які впливають на його відчуття людьми.

Як вже зазначалося, не багато соціологів сьогодні приділяють увагу феномену щастя. Зокрема, на це звернув увагу автор багатьох праць, присвячених цій тематиці, М.Цеслік. Коли він спробував вивчати природу добробуту, помітив, що мало хто з основних соціологів Великобританії займався дослідженням щастя. Вперше про щастя було згадано О.Контом, коли релігія почала втрачати своє значення в суспільстві. Прагнення до щастя - це як спосіб солідарності суспільства в неспокійні часи. За О.Контом, щастя як мета, до якої повинні прагнути люди у сучасному суспільстві - ідеальний стан доброго життя індивідів та суспільства. Його досягнення стає можливим за допомогою осягнення людьми позитивізму, тобто розуміння соціального та природного навколишнього світу через міркування та знання про етику та цінності, що дасть духовність та сенс у свійському суспільстві (Cieslik, 2017). 
М.Цеслік пропонує описувати щастя, відштовхуючись від теорії побудови. Згідно цієї теорії ми конструюємо ментальні уявлення, опираючись на колективні поняття як складові. Схожою до такої теорії є думка Е.Дюркгейма, який у своїх працях “Самогубство” та "Елементарні форми релігійного життя” пояснює, що добробут залежиться від якості соціальних зв’язків між людьми, а ці зв'язки побудовані на традиціях та ритуалах. Відповідно, теорія побудови вказує на залежність щастя від колективних уявлень, через призму яких дивиться індивід (Cieslik, 2017).

Не можна оминути увагою й іншого класика соціології - Т.Парсонса. Він трактував щастя як дихотомію співвідношення “досяжного” (орієнтація на загальнозначущі соціальні характеристики, що забезпечує ідентичність суб'єкта 3 певним соціальним статусом) i “зумовленого” (створеного в результаті орієнтації на іманентно особистісні характеристики). Іншими словами, Парсонс трактував щастя як співвідношення того, чого ти потенційно можеш досягти (наприклад, покупка автомобіля, брендового одягу тощо) із тим, що ти змінити не можеш (твої особистісні характеристики) (Карцева, 2012). 3 цього видно, що щастя носить соціальний характер, хоч це й переживання самого індивіда.

Е.Дюркгайм говорив, що людина без суспільства не може поставити якихось певних рамок, меж щастя, тому що суспільство дає їй це розуміння, оскільки певна культура формує певні ідеали, прагнення, трактує щастя в межах певного періоду, бо культура постійно міняється, i так міняються погляди на щастя (Cieslik, 2017).

У книзі “Самогубство” Е.Дюркгайм вказував на значення соціальної інтеграції для людини. Наприклад, самотні люди більш схильні до самогубства, ніж одружені. Це підтверджує те, що людина не може нормально існувати без взаємодії з іншими з людьми та суспільством загалом. Сучасні дослідження психічного здоров'я підтверджують значення соціальної інтеграції, як основної причини добробуту. Зокрема, А.Горвіц вказує на те, що психічне здоров'я впливає на щастя. Наприклад, люди, які частіше контактують із сім'єю, друзями та сусідами, а також причетні до добровільних організацій, таких як церкви, громадські організації та клуби, повідомляють про краще психічне здоров'я, ніж ті, хто є більш ізольованими (Horwitz, 2009).

Ще одним фактором, який впливає на відчуття щастя є соціальна стратифікація. Нерівності в багатстві, силі, знаннях, впливі та престижі, які визначають статус соціального класу, мають сильний вплив на психічне здоров'я. У суспільствах з низьким рівнем нерівності спостерігається високий рівень психічного здоров'я, тоді як у суспільствах з різкими відмінностями в ресурсах загальне самопочуття людей $є$ гіршим. Ключем до розуміння цієї ситуації є розуміння культурних вимог, які висуває суспільство до індивіда. В основному такою культурною цінністю є матеріальний успіх. Якщо суспільство ставить до людини надто високі вимоги, які вона не здатна досягти, вона буде звинувачувати себе, відповідно у такому суспільстві люди будуть почуватись розчарованими та нещасливими. Протилежною $є$ ситуація у тих суспільствах, де люди можуть досягнути культурних цінностей, які є передбачені у суспільстві (Horwitz, 2009).

Сьогодні про щастя пишуть не лише соціологи та психологи. Економіст Л.Річарда у книзі “Щастя: уроки нової науки” говорить про те, що люди можуть бути щасливими або нещасливими через соціальне порівняння себе (свого рівня життя, доходу) з іншими (родичами, знайомими, сусідами тощо). Значення має те, що відбувається з “референтною групою”, тобто групою собі подібних. Ось чому на Олімпійських іграх бронзові призери задоволені своїми результатом більше, ніж срібні медалісти: бронзові медалісти порівнюють себе з тими, хто не отримав медалей, тоді як срібні призери вважають, що могли б отримати золоту медаль (Лейард, 2012, с. 22).

Не менш важливим фактором, який впливає на відчуття щастя є стосунки з іншими, дружба. 3 цим пов'язане відчуття людиною безпеки. Для людини важливо жити там, де можна довіряти іншим. Отже, $є$ тісний взаємозв'язок між тим, що соціологи називають “соціальним капіталом", та почуттям щастя (Лейард, 2012, с. 39-40).

Р.Веенховен стверджує, що щастя - це сприйняття життя як такого та уявлення про те, яким воно має бути. Постійне збільшення асортименту товарів та послуг, доступних людям, створює проблему, адже “гедоністична бігова доріжка" робить спосіб життя та щастя невловимим. Рекламна індустрія знижує наше самопочуття, оскільки пропагує мрії про життя, яке недосяжне для простої людини (Veenhoven, 2014). 
Опираючись на результати всезагального опитування, проведеного у США, Р.Лейярд виокремив п'ять факторів в порядку убування їх значущості, які впливають на відчуття щастя: сім'я, фінанси, робота, суспільство, друзі і здоров'я. До схожих висновків спонукають опитування World Values Survey (проводяться у всьому світі з 1981 р.): люди, які одружуються є більш щасливіші, ніж самотні; пік щастя в них у перший рік спільного життя.; коли люди розлучаються, у перший рік рівень їхнього щастя падає. Також втрата роботи впливає на зниження рівня щастя (Лейярд, 2012, с.36).

Опитування World Values Survey проводилися також і в Україні. Дані від 2011 р. показали, що дуже щасливими себе почувають $16,1 \%$ опитаних українців, загалом щасливими - $52 \%$, не дуже щасливими - 22,6\%, зовсім нещасливими - 4,2\% опитаних (World Values Survey). У той же час, відповідно до звіту World Happiness Report 2018, опублікованого ООН, Україна опинилась на 138 місці серед 156 країн у рейтингу. За оцінкою американського інституту Gallup - у 2016 році Україна увійшла до трійки країн з найвищими у світі показниками «страждання» населення - 41\% страждаючих. За цим дослідженням 50\% населення країни намагаються вижити, і лише 9\% почувають себе добре. Рейтинг щастя ООН базується на 6 основних показниках: ВВП на душу населення за паритетом купівельної спроможності; рівень соціальної підтримки; очікувана тривалість здорового життя; свобода робити життєвий вибір; рівень щедрості; ступінь сприйняття корупції в країні.

Отже, ми бачимо, що щоб почуватися щасливою, людина повинна в своєму житті бути включена у суспільство, приносити якусь користь. Важливо також, щоб робота приносила задоволення, дозволяла творчо підходити до діяльності. Також на відчуття щастя впливає можливість задоволення потреб. Ще одна цікава думка про щастя зводиться до того, що все залежить від людини і тільки ії судження. “Жодні об'єктивні показники - як фізіологічні (пульс, дихання т. ін.) так соціальні (висока зарплата, хороші житлові умови і т. ін.) - що свідчать з точки зору дослідника, про повне благополуччя респондента, ніякі спостереження i судження людей не є підставою стверджувати, що дана людина задоволена, якщо вона це заперечує" (Паніотто, Сахно \& Пясковська, 2008, с.88)

Аналіз теоретичних джерел та емпіричних даних дає змогу зробити висновок, хоча відчуття щастя i $\epsilon$ індивідуальним переживанням, але саме суспільство впливає на уявлення індивідом про те, що означає бути щасливим. Щастя це те, що залежить від колективних переживань, уявлень (за Е.Дюркгаймом), які згодом впливають на самого індивіда. Ще один вагомий чинник щастя - це соціальні зв'язки, без яких людина втрачає будь-який сенс. Вона істота соціальна, не може бути відокремлена і має відчувати довіру до людей, з якими контактує, щоб відчувати безпеку.

\section{References}

Kartseva, L. V. (2012). Schaste kak sotsyolohycheskaia katehoryia. Vestnyk Kazanskoho tekhnolohycheskoho unyversyteta, 15 (1), 208-210.

Lэiard, R. (2012). Schaste: uroky novoi nauky. M.: Yzdatelstvo Ynstytuta Haidara.

Panniotto V., Sakhno Yu., \& Piaskovska A. (2018). Dynamika rivnia shchastia ta yoho determinanty Ukraina 2001 - 2017. Sotsiolohiia: teoriia, metody, marketynh, (1), 84 - 102.

Yak buty shchaslyvym u bidnii kraini. URL: https://forumkyiv.org/uk/analytics/yak-buti-shaslivimiu-bidnij-krayini

Cieslik, M. (2016). The Happiness riddle and the quest for a good life. Springer.

Horwitz, A. (2017). An Overview of Sociological Perspectives on the Definitions, Causes, and Responses to Mental Health and Illness. In T. Scheid \& E. Wright (Eds.), A Handbook for the Study of Mental Health: Social Contexts, Theories, and Systems (pp. 6-19).

Veenhoven, R. (2014). Why Sociological Theory of Happiness Falls Short. Social Indicators Network News, (119-20), 1-4.

World Values Survey Wave 6: 2010-2014. URL: http://www.worldvaluessurvey.org/WVSOnline.jsp 


\section{Список використаних джерел}

Карцева, Л. В. (2012). Счастье как социологическая категория. Вестник Казанского технологического университета, 15 (1), 208-210.

Лэйард, Р. (2012). Счастье: уроки новой науки. М.: Издательство Института Гайдара.

Панніотто В., Сахно Ю., \& Пясковська А. (2018). Динаміка рівня щастя та його детермінанти Україна 2001 - 2017. Соціологія: теорія, методи, маркетинг, (1), 84 - 102.

Як бути щасливим у бідній країні. URL: https://forumkyiv.org/uk/analytics/yak-buti-shaslivimi-ubidnij-krayini

Cieslik, M. (2016). The Happiness riddle and the quest for a good life. Springer.

Horwitz, A. (2017). An Overview of Sociological Perspectives on the Definitions, Causes, and Responses to Mental Health and Illness. In T. Scheid \& E. Wright (Eds.), A Handbook for the Study of Mental Health: Social Contexts, Theories, and Systems (pp. 6-19).

Veenhoven, R. (2014). Why Sociological Theory of Happiness Falls Short. Social Indicators Network News, (119-20), 1-4.

World Values Survey Wave 6: 2010-2014. URL: http://www.worldvaluessurvey.org/WVSOnline.jsp 